Original Research Article

\title{
Anticonvulsant activity of Adhatoda vasica leaves by pentylenetetrazol model: preliminary evaluation in rats
}

\author{
Sumitha A. ${ }^{1 *}$, Dhanasekaran R. ${ }^{2}$, Prathiba A. ${ }^{3}$, Geetha M. ${ }^{4}$
}

\begin{abstract}
${ }^{1}$ Department of Pharmacology, ACS Medical College and Hospital, Chennai, India ${ }^{2}$ Department of Paediatrics, Madras Medical college and Hospital, Chennai, India ${ }^{3}$ Department of Pathology, ACS Medical College and Hospital, Chennai, India

${ }^{4}$ Department of Pharmacology, JJM Medical college, Davangere, Karnataka, India
\end{abstract}

Received: 20 May 2019

Revised: 10 June 2019

Accepted: 02 July 2019

*Correspondence to:

Dr. Sumitha A,

Email: arum.sumithadr@ gmail.com

Copyright: (C) the author(s), publisher and licensee Medip Academy. This is an openaccess article distributed under the terms of the Creative Commons Attribution NonCommercial License, which permits unrestricted noncommercial use, distribution, and reproduction in any medium, provided the original work is properly cited.

\begin{abstract}
Background: Epilepsy is a disorder characterised by recurrent seizures of cerebral origin with episodes of sensory, motor phenomenon with or without loss of consciousness. The present study was taken up to evaluate the anticonvulsant effect of aqueous extract of leaves of Adhatoda vasica in rats. Objectives of this study is to evaluate the effect of aqueous extract of Adhatoda vasica leaves on Pentylenetetrazol induced seizures in albino rats and to compare the effect of aqueous extract of Adhatoda vasica leaves with standard dose of sodium valproate on Pentylenetetrazol induced seizures in albino rats.

Methods: Anticonvulsant activity of aqueous extract of Adhatoda vasica was analysed using PTZ (Pentylenetetrazol) model. Groups used were distilled water as control group, Sodium valproate as standard for Pentylenetetrazol and two doses of aqueous extract of Adhatoda vasica (100mg/kg and $200 \mathrm{mg} / \mathrm{kg}$ ) for this screening model. Parameters observed for PTZ models were abolition of clonic seizures and time duration between injection of PTZ and onset of seizures.

Results: In PTZ model, test group at $200 \mathrm{mg} / \mathrm{kg}$ showed $33.33 \%$ protection for abolition of clonic seizures, though not comparable to standard group. There was significant increase in the duration of onset of clonic seizures after PTZ injection in both test groups (at $100 \mathrm{mg} / \mathrm{kg}$ and $200 \mathrm{mg} / \mathrm{kg}$ ) when compared to control group.

Conclusions: Aqueous extract of leaves of Adhatoda vasica has shown significant anticonvulsant action in PTZ model.
\end{abstract}

Keywords: Adhatoda vasica, Aqueous extract, PTZ, Sodium valproate

\section{INTRODUCTION}

Epileptic seizures arise from an excessively synchronous and sustained discharge of a group of neurons. The single feature of all epileptic syndromes is the persistent increase of neuronal excitability. Paroxysmal depolarisation shift (PDS) of neuronal membrane potential and associated burst discharge are believed to be a characteristic pathophysiologic event in a seizure. ${ }^{1}$ More than $80 \%$ of people with epilepsy are in developing countries. ${ }^{2}$ The prevalence rate of epilepsy in India is 5.59-10 per $1000 .^{3,4}$ It has been estimated that 2.4 million new cases occur each year globally. ${ }^{5}$ The sex distribution of epilepsy is slightly skewed towards male sex i.e. the disease has a male preponderance. ${ }^{6}$ The major goal of anti-epileptic therapy is to allow patients to maintain a normal lifestyle by complete control of seizures with minimal side effects. Unfortunately, many of the antiepileptic drugs discovered 
are associated with dose limiting side effects, adverse reactions and risk of toxicity through drug-drug interactions. $^{7}$ The long term use of herbs introduced in traditional medicines confirm their value in drug discovery. ${ }^{8}$ Herbal products like Apium graveolens linn.(Ajmoda), Eryngium foetidum linn (Brahmadhaniyaa), Pterocarpus santalinus linn (Raktachandana), Acorus calamus linn. (Ugragandha) have shown to have anticonvulsant effect in traditional medicine. ${ }^{9}$

Leaves of Adhatoda vasica has got immense medicinal properties. Essential oils and alkaloids like vasicine, vasicinone, deoxy vasicine are being found in Adhatoda vasica leaves. ${ }^{10}$ To explore its effect on anticonvulsant activity, preliminary evaluation in rats by PTZ model is being done in this study. Objectives of this study is to evaluate the effect of aqueous extract of Adhatoda vasica leaves on Pentylenetetrazol induced seizures in albino rats and to compare the effect of aqueous extract of Adhatoda vasica leaves with standard dose of sodium valproate on Pentylenetetrazol induced seizures in albino rats.

\section{METHODS}

\section{Source of data}

After the approval from Institutional Animal Ethics Committee, this study was done in Department of Pharmacology, JJM Medical College, Davangere, Karnataka, India.

\section{Experimental animals}

Albino rats (male and female), weighing 150-200gms bred in central animal house of J.J.M. Medical College, Davangere, was used for the study.

\section{Chemicals and drugs}

Chemicals used in this study were Injection of Pentylenetetrazol- $60 \mathrm{mg} / \mathrm{kg}$, Injection of Sodium valproate- $300 \mathrm{mg} / \mathrm{kg}$, Aqueous extract of Adhatoda vasica leaves $-100 \mathrm{mg} / \mathrm{kg}$ and Aqueous extract of Adhatoda vasica leaves- $200 \mathrm{mg} / \mathrm{kg}$.

\section{Extract}

Aqueous extract of Adhatoda vasica leaves was obtained from Natural remedies company, Bangalore.

\section{Inclusion Criteria}

- Animals weighing 150-200gm albino rats (Both male and female).

- Healthy animals with normal behavior.

\section{Exclusion Criteria}

- Pregnant female rats.
- Animals used for any other experimental procedure in the past 1 month.

\section{Experimental method}

Pentylenetetrazol (PTZ) model:

24 albino rats were divided in to 4 groups of 6 animals each with distribution of both male and female rats.

- Group A: Received distilled water $10 \mathrm{ml} / \mathrm{kg}$ i.p. as control.

- Group B: Received Inj. Sodium valproate 300 mg/kg i.p. as standard ${ }^{11}$

- Group C: Received Inj. Aqueous extract of Adhatoda vasica $-100 \mathrm{mg} / \mathrm{kg}$ i.p.

- Group D: Received Inj. Aqueous extract of Adhatoda vasica $-200 \mathrm{mg} / \mathrm{kg}$ i.p.

All the injections were given 30 minutes before the administration of Pentylenetetrazol which was given at a dose of $60 \mathrm{mg} / \mathrm{kg}$. The animals were weighed, and then appropriate dose of the drug was injected intraperitoneally to different groups. After an interval of 30 minutes, 60 $\mathrm{mg} / \mathrm{kg}$ of Pentylenetetrazol was injected intraperitoneally. The animal was kept in transparent plexiglass during the clonus to prevent any injury.

\section{Parameters observed in Pentylenetetrazol model}

- Abolition of clonic seizures was taken as an index of anticonvulsant activity.

- Time duration between injection of Pentylenetetrazol and onset of seizures.

\section{Evaluation}

Abolition of clonic seizures was taken as an index of anticonvulsant activity. Increased time duration between injection of PTZ and onset of seizures i.e. latency of clonic seizures shows that anticonvulsant is more effective.

\section{Statistical analysis}

Protection in PTZ induced seizures were recorded as percentage of protection. Other values expressed as mean and standard deviation. Statistical significance was calculated by ANOVA and Post-hoc Tukey's test used for inter group comparison. $\mathrm{p}<0.05$ was taken as significant.

\section{RESULTS}

In PTZ model, all the 6 animals in control group showed clonic seizures $(0 \%$ protection) when compared to all 6 animals protected in standard sodium valproate group (100\% protection). In group C $(100 \mathrm{mg} / \mathrm{kg}$ of aqueous extract of Adhatoda vasica), all 6 animals showed clonic seizures showing $0 \%$ protection. In group D $(200 \mathrm{mg} / \mathrm{kg}$ of 
Adhatoda vasica), 2 animals were protected from clonic seizures showing $33.33 \%$ protection as shown in Table 1 .

Table 1: Group wise comparison of abolition of clonic seizures in PTZ model (percentage of protection) Clonic Seizures in PTZ Model.

\begin{tabular}{|ll|}
\hline Drugs given & $\begin{array}{l}\% \\
\text { Protection }\end{array}$ \\
\hline Group A (Distilled water-10ml $/ \mathrm{kg})$ & $0(0 \%)$ \\
\hline Group B (Sodium Valproate- $300 \mathrm{mg} / \mathrm{kg})$ & $6(100 \%)$ \\
\hline Group C (Adhatoda vasica-100 $\mathrm{mg} / \mathrm{kg})$ & $0(0 \%)$ \\
\hline Group D (Adhatoda vasica-200 $\mathrm{mg} / \mathrm{kg})$ & $2(33.33 \%)$ \\
\hline
\end{tabular}

Adhatoda vasica at $100 \mathrm{mg} / \mathrm{kg}$ and $200 \mathrm{mg} / \mathrm{kg}$ showed significant increase in the duration of onset of clonic seizures after PTZ injection when compared to control as shown in Table 2. There was increase in the duration of onset of clonic seizures in group $\mathrm{C}$ and group $\mathrm{D}$ and it was statistically significant when compared to control $\mathrm{p}<0.02$ as shown in Table 3.

Table 2: Showing comparison of mean duration of onset of clonic seizures after PTZ injection in different groups in PTZ Model.

\begin{tabular}{|c|c|c|c|}
\hline & Mean & $\begin{array}{l}\text { Standard } \\
\text { deviation }\end{array}$ & ANOVA \\
\hline $\begin{array}{l}\text { Group A (Distilled } \\
\text { water- } 10 \mathrm{ml} / \mathrm{kg} \text {.) }\end{array}$ & 25 & 10.49 & \multirow{4}{*}{$\begin{array}{l}F=8.62, \\
p<0.001 \\
\text { Significant }\end{array}$} \\
\hline $\begin{array}{l}\text { Group B (Sodium } \\
\text { Valproate } 300 \\
\mathrm{mg} / \mathrm{kg} \text { ) }\end{array}$ & 0 & 0 & \\
\hline $\begin{array}{l}\text { Group C (Adhatoda } \\
\text { vasica } 100 \mathrm{mg} / \mathrm{kg} \text { ) }\end{array}$ & 140 & 52.54 & \\
\hline $\begin{array}{l}\text { Group D (Adhatoda } \\
\text { vasica } 200 \mathrm{mg} / \mathrm{kg} \text { ) }\end{array}$ & 145 & 114.58 & \\
\hline
\end{tabular}

Table 3: Tukey's post-hoc multiple comparison test in PTZ model showing difference between groups in the duration of onset of clonic seizures.

\begin{tabular}{|lll|}
\hline Groups & $\begin{array}{l}\text { Mean } \\
\text { Difference }\end{array}$ & $\begin{array}{l}\text { Significance } \\
(\mathbf{p}<0.05)\end{array}$ \\
\hline Group A and C & 115.00 & $\mathrm{P}<0.02$ Significant \\
\hline Group A and D & 120.00 & $\mathrm{P}<0.02$ Significant \\
\hline Group C and D & 5.00 & $\begin{array}{l}\mathrm{P}>0.05 \text { Not } \\
\text { Significant }\end{array}$ \\
\hline
\end{tabular}

Aqueous extract of Adhatoda vasica at $200 \mathrm{mg} / \mathrm{kg}$, showed protection against clonic seizures and also increased the mean duration of onset of clonic seizures after PTZ injection in albino rats when compared to control as shown in Table 1 and 2 respectively. Bar diagram depicting percentage of animals showing abolition of clonic seizures shown in figure 1.

Comparison of mean values of duration of onset of clonic seizures after PTZ injection shown in figure 2.

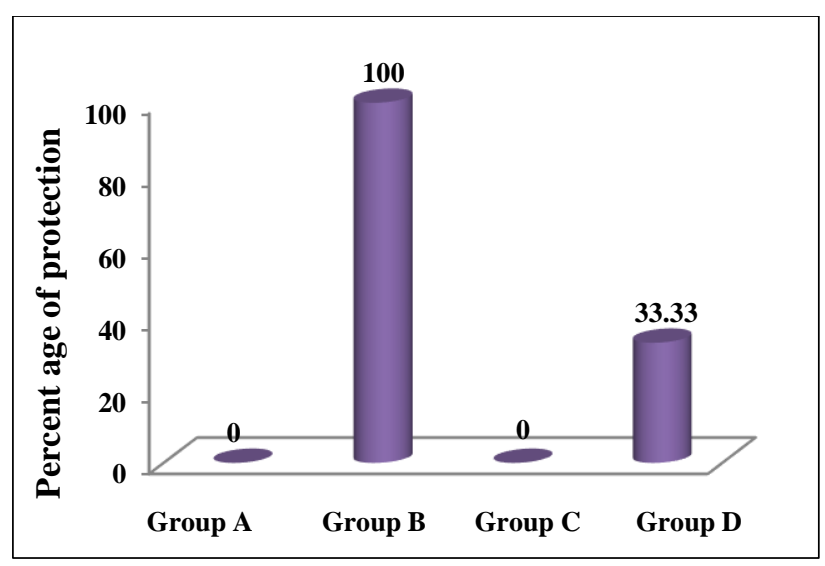

Figure 1: Bar diagram depicting percentage of animals showing abolition of clonic seizures in PTZ model.

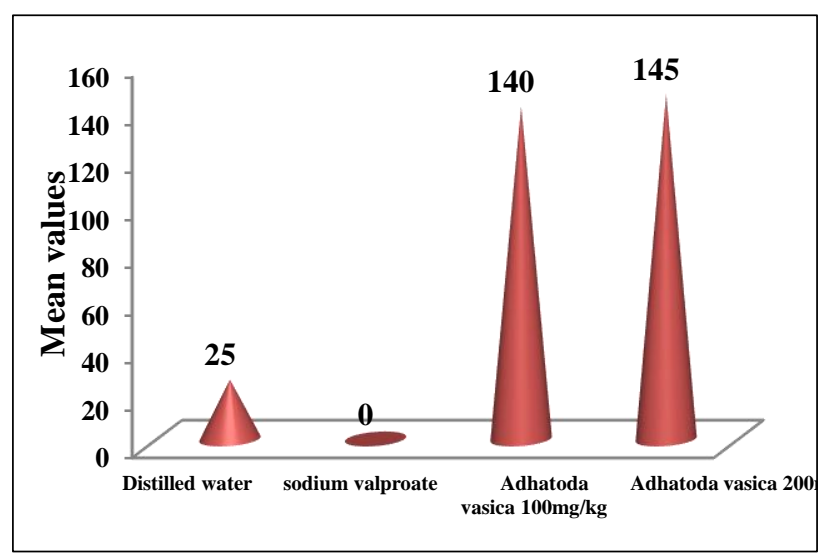

Figure 2: Bar diagram depicting comparison of mean values of duration of onset of clonic seizures in PTZ model.

\section{DISCUSSION}

This study analyses anticonvulsant activity of aqueous extract of Adhatoda vasica leaves in albino rats and also to compare its effect with standard drug sodium valproate. Leaves of Adhatoda vasica are long and bitter to taste. ${ }^{12}$ All parts of Adhatoda vasica plant are used in herbal medicine and particularly the leaves are endorsed with insecticidal and parasiticidal properties. PTZ is a CNS convulsant acts at the picrotoxin site of the Gaba amino butyric acid type A (GABA A) receptor decreasing the $\mathrm{Cl}$ current in a concentration dependant manner. PTZ is being used as a convulsant to induce chemical induced seizures in animal models. Parameters assessed in PTZ model were abolition of clonic seizures and time duration between injection of Pentylenetetrazol and onset of seizures. In group A, normal saline used as control. This group showed $0 \%$ protection from seizures as clonic seizures was shown by all 6 animals with PTZ injection. Standard drug sodium valproate in group B $(300 \mathrm{mg} / \mathrm{kg})$ showed maximal $(100 \%)$ protection from clonic seizures shown in Table 1.

In group C $(100 \mathrm{mg} / \mathrm{kg}$ of aqueous extract of Adhatoda vasica) showed $0 \%$ protection from clonic seizures with 
PTZ injection as shown in Figure 1. Group D $(200 \mathrm{mg} / \mathrm{kg}$ of aqueous extract of Adhatoda vasica) showed $33.3 \%$ protection from clonic seizures as shown in Table 1. In Group C, mean duration of onset of clonic seizures after PTZ injection was 140 when compared to control group value of 25 as shown in Table 2. Statistically significant increase in duration of onset of clonic seizures when compared to control group $(\mathrm{p}<0.02)$ shown in Table 3. While the results were not comparable to standard sodium valproate, as in this group all the animals were protected from seizures. This implies that aqueous extract of Adhatoda vasica at $100 \mathrm{mg} / \mathrm{kg}$ has anticonvulsant activity in PTZ model. In group D(Adhatoda vasica $200 \mathrm{mg} / \mathrm{kg}$ ), the mean duration of onset of clonic seizures after PTZ injection was 145 when compared to control group value of 25 , but the results were not comparable to standard sodium valproate group. But when groups $\mathrm{C}$ and $\mathrm{D}$ were compared for mean duration of onset of clonic seizures after PTZ injection, statistically non-significant $\mathrm{p}>0.05$ results were obtained as shown in Table 3 .

Many drugs that are used today in the treatment of epilepsy provide better relief, however their considerable side effects have prompted considerable research in discovering new or related compounds that retain the beneficial action without the adverse effects. Thus, Adhatoda vasica will be a better herbal remedy in discovery of newer drug. Alcoholic extract of Adhatoda vasica leaves at 100,150 and $200 \mathrm{mg} / \mathrm{kg}$ in a study done by Gangaraju et al, shown dose dependant protection from seizures in PTZ model. ${ }^{13}$

In this study also in PTZ model, aqueous extract of Adhatoda vasica at $100 \mathrm{mg} / \mathrm{kg}$ and $200 \mathrm{mg} / \mathrm{kg}$ has shown similar results. Adhatoda vasica leaves revealed the presence of phytochemicals tannins, flavonoids, alkaloids, saponins and steroids by preliminary analysis.8Active substances reported for anticonvulsant activity were phytochemicals like tannins, steroids as shown in the study done by Ambawade SD. ${ }^{14}$ Exact active compound responsible for anticonvulsant activity needs to be analysed by further extended studies to make this herbal compound beneficial for human beings.

\section{CONCLUSION}

After observing the results of the present study, aqueous extract of Adhatoda vasica leaves has shown significant anticonvulsant action in Pentylenetetrazol(PTZ) model. It may prove beneficial for newer development of anticonvulsant drug, but there is need for further studies on other experimental animals and human beings to establish its usefulness, exact mode of action.

\section{ACKNOWLEDGEMENTS}

Author would like to thank wholeheartedly Natural remedies company, Bangalore, for supplying aqueous extract of Adhatoda vasica for my study.
Funding: No funding sources

Conflict of interest: None declared

Ethical approval: The study was approved by the Institutional Ethics Committee

\section{REFERENCES}

1. Satoskar RS, Bhendarkar SD, Rege NN. Drugs effective in Seizure disorders. In: Satoskar RS, Bhendarkar SD, Rege NN, eds. Pharmacology and Pharmacotherapeutics. 23 $3^{\text {rd }}$ ed. Mumbai: Popular Prakashan; 2013: 129-48.

2. Leonardi MT, Ustan TB. The global burden of Epilepsy. Epilepsia. 2002;43:21-5.

3. Gourie-Devi M, Gururaj G, Satishchandra P, Subbakrishna DK. Prevalence of neurological disorders in Bangalore, India: a community-based study with a comparison between urban and rural areas. Neuroepidemiol. 2004;23(6):261-8.

4. Goel D, Agarwal A, Dhanai JS, Semval VD, Mehrotra V, Saxena V, et al. Comprehensive rural epilepsy surveillance programme in Uttarakhand state of India. Neurology India. 2009 May 1;57(3):355-6.

5. Ganaie SA, Bashir A. Epilepsy in Kashmir, J\&K Childhood Seizures \& Epilepsy, Types, Causes, Diagnosis, Intervention, Prevalence and Action. Int $\mathbf{J}$ Translation Community Dis. 2014;2(2):13-20.

6. Honavar M, Meldrum BS. Epilepsy. In: Graham DL, Lantos PL, editors. Greenfield's neuropathology. $7^{\text {th }}$ ed (vol I). London: Arnold; 2002:99-922.

7. Gerlach AC, Krajewski JL. Antiepileptic drug discovery and development: what have we learned and where are we going. Pharmaceuticals. 2010;3:2884-99.

8. Butler MS. The role of natural product chemistry in drug discovery. J Nat Prod. 2004;67:2141-53.

9. Khare CP. Indian medicinal plants,an illustrated dictionary. $2^{\text {nd }}$ ed. New York: Springer;2007:178-9.

10. Gangwar AK, Ghosh AK. Medicinal uses and Pharmacological activity of Adhatoda vasica. Int $\mathbf{J}$ Herbal Med. 2014;2(1):88-91.

11. Tandon VR, Gupta RK. An Experimental evaluation of anticonvulsant activity of Vitex Negundo. Indian J Physio Pharmacol. 2005;49(2):199-205.

12. Lone SA, Yadav AS, Sharma AK, Tafazul M, Raghuwanshi DK, Yogeshbadkhane. A review on Adhatoda vasica Nees- An important and high demanded medicinal plant. 2013;3(3):2600-15.

13. Ganga Raju M, Fernandes J, Vijayanarayana K. Evaluation of antiepileptic activity of the alcoholic extract of Adhatoda vasica leaves in rats. Res $\mathbf{J}$ Pharmaceut Biol Chem Sci. 2011;2(3):5-10.

14. Ambawade SD, Kasture VS, Kasture SB. Anticonvulsant activity of roots and rhizomes of Glycyrrhiza glabra. Ind J Pharmacol. 2002;34(4):251-55.

Cite this article as: Sumitha A, Dhanasekaran R, Prathiba A, Geetha M. Anticonvulsant activity of Adhatoda vasica leaves by PTZ model: preliminary evaluation in Rats. Int J Basic Clin Pharmacol 2019;8:1703-6. 